\title{
スピーカー型シンセティックジェットによる 浮き上がり火炎の能動制御*
}

\author{
小河原 加久治*1, 西 村 龍 夫*1, 桑 原 大 輔*2 \\ 北澤 雅 之*1, 石田 喜一*2
}

\section{Active Control for Lifted Flame using a Speaker-Driven Synthetic Jet}

\author{
Kakuji OGAWARA*3, Tatsuo NISHIMURA, Daisuke KUWAHARA, \\ Masayuki KITAZAWA and Yoshikazu ISHIDA \\ *3 Department of Mechanical Engineering, Yamaguchi University, \\ 2-16-1 Tokiwadai, Ube-shi, Yamaguchi, 755-8611 Japan
}

\begin{abstract}
Lifted flame would be helped high-intensity combustion system like gas turbine for $\mathrm{NO}_{\mathrm{x}}$ reduction and improve the limit of flame's blowing off. While lifted flame has various instabilities, flame control technology is necessary for fame stabilizing. In this paper, a speaker-driven synthetic jet actuator for lifted flame control is proposed, and the active control of the height of lifted flame is performed using this actuator. This type of actuator has the advantage of fitting to existing combustion systems and produces high speed jet. Th performance of the speaker-driven synthetic jet actuator is examined by experiments that reduce the height of lifted flame of a propane diffusion flame. In the active control of the height of lifted flame, the Delayed Feedback Control method considering delay time for a control law is applied. The frequency of synthetic jet is fixed and velocity of jet is changed by the control law. The results show that the synthetic jet can lower the instabilities of lifted flame.
\end{abstract}

Key Words : Active Control, Lifted Flame, Speaker-Driven, Synthetic Jet Actuator

\section{1. 粕 㴔}

ガスタービンに代表される実用の燃焼場では, 高 い熱量を得るために高負荷燃焼が行われる.このとき 火炎の吹き飛びを防ぐ保炎技術が重要な問題となる. その対策として, 従来ではスワーラーやブラフボディ を使用して循環流を発生させる方法が用いられるが, これらの受動的制御では火炎を意図した燃焼状態に維 持することは難しい. 非定常な挙動を示す火炎をさま ざまな流動条件の下で制御するためには，燃焼場への 状態フィードバックが不可欠である.

今後の燃焼器には高負荷, 高効率の他にクリーン な燃焼技術が求められる. 最近の燃焼研究において, 環境污染物質である NOx の排出低减に浮き上がり火

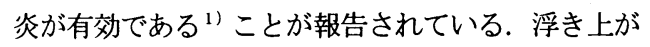
り火炎とは, 火炎がバーナリムから浮き上がり, 浮き 上がった状態で火炎が留まる現象である. 火炎基部上 流で空気と燃料の混合が促進されるため, NOx 低减 に効果的な火炎形態であると指摘されている. この現

\footnotetext{
* 原稿受付 2005 年 7 月 19 日.

*1 正員, 山口大学工学部( 755 -8611 宇部市常盤台 2-16-1).

*2 山口大学大学院理工学研究科.

E-mail : ogawara@ yamaguchi-u.ac.jp
}

象は, 燃料噴出速度だけでなく燃焼器の構造や然料の 種類によっても異なる. そして，この状態を放置する と火炎の吹き飛びを引き起こす危険性があることから， その保炎制御技術が必要となる.

既往の浮き上がり火炎制御の研究として, マイク ロアクチュエータ群による制御2、3) やスピーカーを 用いた制御 ${ }^{4)}$ が効果を挙げている. 前者はノズル内 壁に設けた 18 個の電磁アクチュエータを, 後者は整 流部の壁に取り付けたスピーカーを用いることで，混 合気に変動を加え, 浮き上がり火炎を安定化させてい る.しかし、これらの制御装置では構造が複雑で既存 の燃焼設備に対しての設置が難しいという問題がある.

本研究では，構造が簡易で既存装置にも取り付け が可能なスピーカー型シンセティックジェットアクチ ユエータ（SSJA）を開発し，実際に浮き上がり火炎 に対する有効性を示した. そして，シンセティックジ エットにより火炎リフト高さを能動制御し, 浮き上が り火炎の安定化を目的とした.

\section{2. スピーカ一型シンセティックジェット}

火炎を吹き消すことなく火炎基部上流で周囲空気 と燃料との混合を促進するためには，周囲流体への吹 
き出しと吸い込み動作を可能とするシンセティックジ エットアクチュエータが有効であると思われる．本研 究では，その駆動動力として作製，制御が容易である という観点からスピーカーを用いた. スピーカーを用 いた既往の研究として，スピーカーによって励起した 空気噴流の特性を調査し, 推進機構として忘用する研 究が行われているら

2. 1 SSJA の構造 図 1 にSSJA の概観と構造 を示す。本アクチュェータは, スピーカー (PIONEER TS-W202F)，縮流部およひ整流部で構 成されている。信号発生器 (HEWLLET PACKARD 3312A）で矩形波信号を生成し，アンプ（SONY TAV7700) によって堌幅後, スピーカーに入力し，吹き

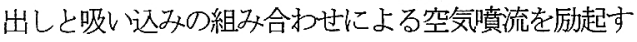
る. アクチュエータの出口部における噴流の流速と周 波数は，アンプへの入力電王と信号の周波数によって 変化させる.

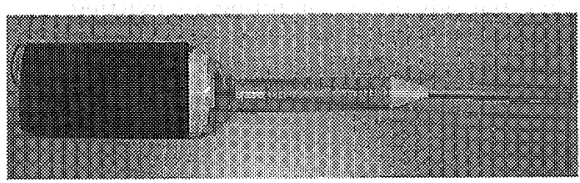

(1) Speakerbox (3)\&(5) Contraction cone

(2) Speaker (4)\&(6) Settling chamber

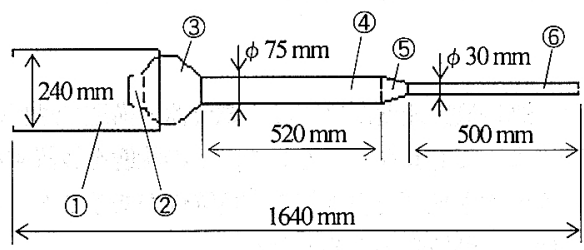

Fig.1 Speaker-driven syntheticjetactuator

22 アクチュエータ特性実験 本アクチュエ 一タは，スピーカーに縮流部と整流部を取り付けるこ とで，スピーカ一単体とは異なる特性を持つ、スピー カ一，縮流部及ひ整流部の個々の基本的特性を調査す るために，図2に示各型における出口流速を熱線流 速計 (TESTO 425) で測定した. 各型の寸法值は図 1 と同様である. Type D はスピーカーボックス後端が密 閉されているが，その他の型は後端が開放されており， 空気の流入が可能となっている. 熱線流速計は噴流出 ロ中央から $1 \mathrm{~cm}$ 離れた位置に設置した。ここで，シン セティックジェットの特性上，流速は常に変化してい るため 10 秒間の平均流速を流速と呼ぶことにする. 図 3は各型における噴流の周波数に対する出口流速 を示している. ただし，アクチュエータへの人力電 压は全て $13.5 \mathrm{~V}$ (30Hzのとき) とした.ここで, 各
型（Type A〜D）の流速が，どの周波数で最大とな るかを明確にするために，図 3 中に各型の流速の最 大值加横軸（周波数軸）に対して垂線（破線）を 加えた.

スピーカー単体 (Type A) の場合は, 30Hzで最速と なる．スピーカー噴流の流速は振動板の振幅に左右さ れるため, 入力信号の周波数が低、程噴流の流速は速 くなる.しかし，低い周波数でスピーカーを正確に駆 動することは難しく，本研究で用いたスピーカーの再 生周波数带域は 25 4000Hz であるため, 本実験では 30Hz のとき最大流速を示した，スピーカー単体では 入力周波数による流速の差が顕著ではなく，最大流速 も他のタイプに比較して低い：スピーカー単体に縮流 部を設ける（Type B）と，再生周波数帯域下限におい て流速が最大となる。さらに，整流部を装着する (Type C) と再生周波数帯域の下限より低い周波数 $(15 \mathrm{~Hz})$ において最大流速を示した，そして，その值 は縮流比に対応した流速となった．また，スピーカー 後端の開閉の影響については（Type Cと Type D），ス ピーカー後端を開放した方が速い流速を得ることがで き，流速のピークも顕著であることが分かる.

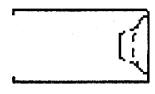

Type A (Speaker only)

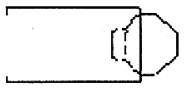

Type B (With Contraction cone(3))

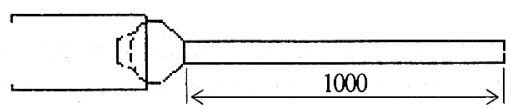

Type C (With Contraction oone(3) and Setting chamber(4))

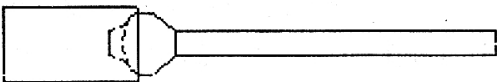

Type D (The back of speaker box is sealed)

Fig.2 Some types of the actuator used in the experiment

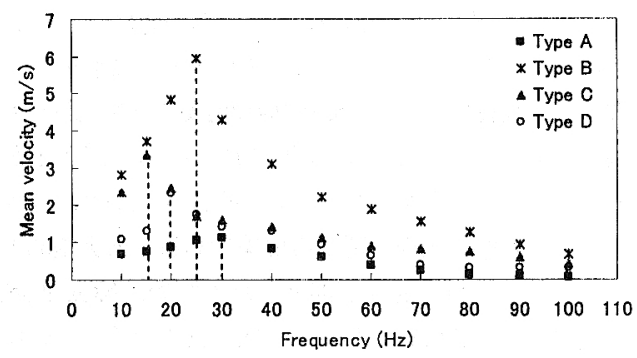

Fig.3 Relation between velocity and frequency of syntheticjet (Type A D) 
アクチュエータへの入力電圧一定の条件で, 図 2 に 示した各型のアクチュエータ以上の流速を得るために は，さらに縮流比を大きくする必要がある. そこで, 図 4 に示すような縮流部の組み合わせを考案した．同 様に測定結果を図 5 に示す.

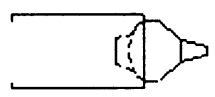

Type E (With Contraction one(3)\&(5))

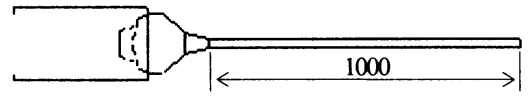

Type F (With Contraction cone (3)\&(5) and Setting chamber(6)

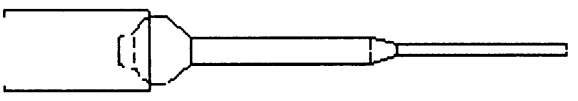

Type G

Fig.4 Some types of the high velocity actuator

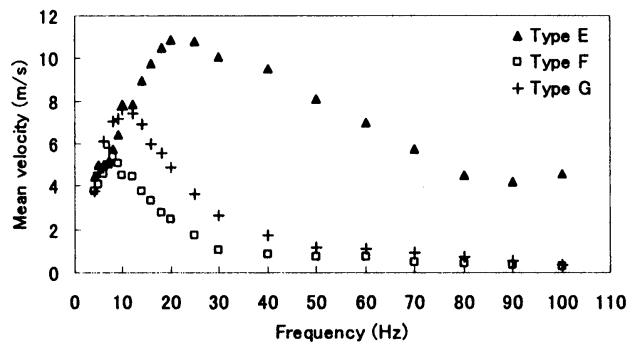

Fig.5 Relation between velocity and frequency of syntheticjet

(TypeE-G)

図 3, 図 5 からアクチュエータ出口での最大流速と 周波数の関係は，縮流部と整流部の有無によって変化 することが分かる． 縮流部のみの場合（Type B， E） の最大流速が最速であった. 一方，整流部を設けた場 合（Type C, D, F, G）ではスピーカーの再生周波数 帯域下限より低い周波数（10２0Hz）において流速に ピークがある.この結果は，縮流部に整流部を設置し た場合は流速のピークが顕著であるという報告 ${ }^{5)}$ と 一致する. 噴流の流速が速い程，火炎に与える影響は 大きくなるが，流速分布が一様でない場合はその影響 が一様でない. そこで, アクチュエータ出口の流速分 布を調査し，流速の一様性を確認することにした. ア クチュエータ出口中央を原点として熱線流速計を上下 に移動させ，各点における流速を測定した. Type E と Type G の測定結果を図 6, 図 7 に示寸. 図 6から縮流 部のみ（Type E），出口流速は速くなるが流速分布が 一様でなくなる.この傾向は中心から離れるにしたが って著しくなる. 一方, 整流部を設けた場合（Type G）は，図 7 に示すように流速の一様性が縮流部出口
に比べて改善されている. また, Type Gは Type Eに 比べて流速のピークが顕著であることから，入力周波 数によって流速を制御することが容易であると考えら れる. 以上から，浮き上がり火炎制御を目的とした SSJA の構成には，縮流部と整流部をそれぞれ二つ備 えた TypeGを適用した.

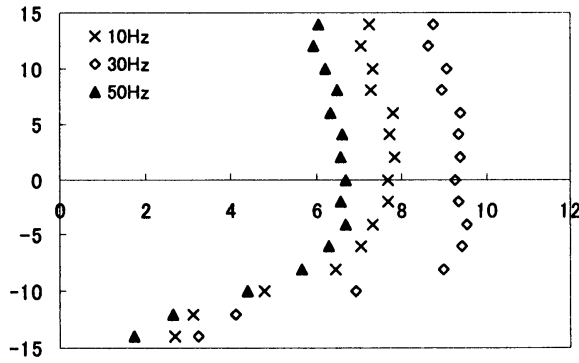

Mean Velocity $(\mathrm{m} / \mathrm{s})$

Fig.6 Velocity distribution at the outlet (Type E)

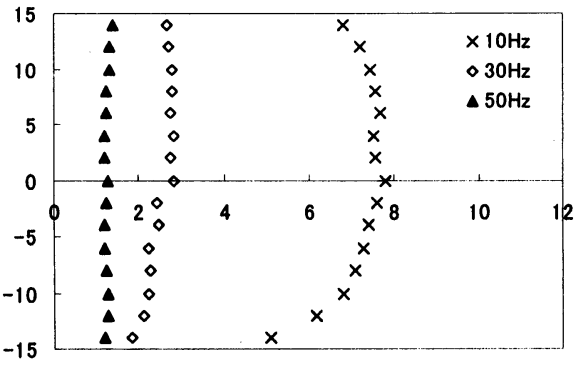

Mean Velocity $(\mathrm{m} / \mathrm{s})$

Fig.7 Velocity distribution at the outlet (Type G)

\section{3. 浮き上がり火炎の計測}

本章では制御対象である浮き上がり火炎を観察し， その安定性について考察する. 本実験には燃焼器にブ ラフボディ型然焼器を使用し, 燃料にプロパンを用い た. 図 8 に燃焼装置の概略を示す. 燃料は圧力調整機 において圧力を調整し，ローターメータにおいて流量 を制御して燃焼器に供給される. 燃焼器は同轒流型 になっており, ブラフボディ中央部のノズル（内径 $\mathrm{D}=3[\mathrm{~mm}]$ ) より燃料を噴出する.

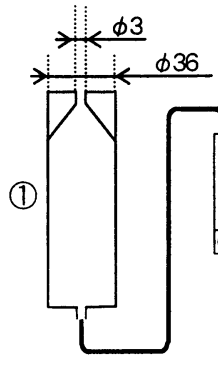

(1) Bluff-bodybumer

(2) Rotameter

(3) Rechwedpressureadjuster

(4) Propanegas vessel

(2)

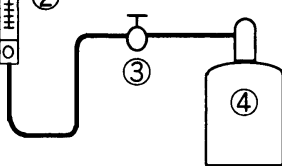

Fig.8 Combustion equipment 
実験はブラフボディ型燃焼器において，静止空気 中にノズルから燃料を噴出させ，そこに形成される 桩散火炎を CCD カメラにより撮影した。図 9 に本 実験において観察される噴流拡散火炎の各燃料流速 における瞬時画像を示す。ここで, H/D は燃料噴出 ロから火炎基部までのリフト高さ $\mathrm{H}$ とノズル径 D の比を示し，この比により火炎のリフト高さを表す.

図 9加㷋形態は大きく分けて付着火炎と浮き 上がり火炎の 2 種類に分類される.ここで，付着火 炎とは火炎基部がバーナリムに付着した状態で安定 している火炎であり，浮き上がり火炎とは火炎基部 がバーナリムから浮き上がり，浮き上がった状態で 留まっている火炎である. 図 9 において(a)は付着 火炎，(b)〜(f)は浮き上がり火炎となっている。

図 10 に燃料流速 $\mathrm{U}_{\mathrm{j}}$ と H/D の変動範用の関係を示す. $\mathrm{U}_{\mathrm{j}}$ の増加に伴って HD は線形的に増加し，それに伴 なって H/D の変動も増加して燃焼騷音の発生が顕著 になる：ここで，火炎の安定性については椂々な見方 があり，火炎の吹き飛び，浮き上がり，燃焼振動・騷 音などの不安定要素の抑制を実現することが火炎の安 定性の見方である. 浮き上がり火炎の特性としてりフ 卜高さが大きくなるほど，火炎基部上流の部分予混合 化が促進され，低 NOx 燃焼が期待できる ${ }^{2)}$. しかし， リフト高さの増大に伴って吹き飛びの危険性が高まり， 図 10 に示したようにリフトの変動も増大することか ら然燒振動や然焼騒音の発生が問題となる.このよう に，浮き上がり火炎の安定性には炏炎のリフト高さが 媣く関わることから, 本研究では HD を火炎の状態 量として扱う. HDが抑制され，その変動が小さい場 合において，火炎が安定したと見なしている。

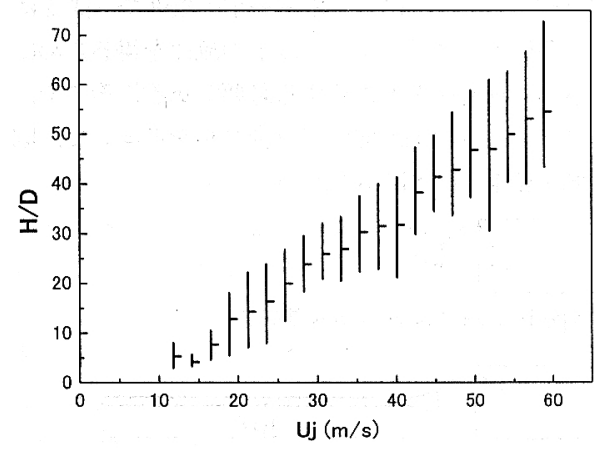

Fig.10 Relation between fuel velocity and lifted height

\section{SSIA の浮き上がり火炎に対する有效性}

本章においては，考案した SSJA の浮き上がり火炎 に対する有効性について確認する. 図 11 に実験装置 の概略を示寸. 本実験は，ブラフボディ型然焼器にお いて形成した浮き上がり火炎の火炎基部に対して，噴 流（シンセティックジェット）を噴出することで行う。 ただし，燃料流速は $\mathrm{U}_{\mathrm{j}}=25.9[\mathrm{~m} / \mathrm{s}]$ とし，H/D =0に固 定した．計算機で生成した矩形波信号をアンプにより 増幅し，アクチュエータに入力することで噴流を励起 させる.アアクチュエータは噴出口をノズル先端より水 平方向に $5 \mathrm{~cm}$ ずらし, $15 \mathrm{~cm}$ 離して設置した.これは 噴流が火炎を吹き消すことなく，有効に作用する位置 を実験的に求めたものである.アクチニエータへの入 力周波数と入力電死を恋化させ，同じ入力周波数の場 合でも異なる流速の噴流を誘起させるようにした，火 炎の撮影は高速度カメラ (PHOTRON Fastcam-X1280, 解像度 : $256 \times 1280$ pixel, 濃度表現 : カラー 8 bit）によ り，125 Hz (シャッタースピード1/125 s) で行った.

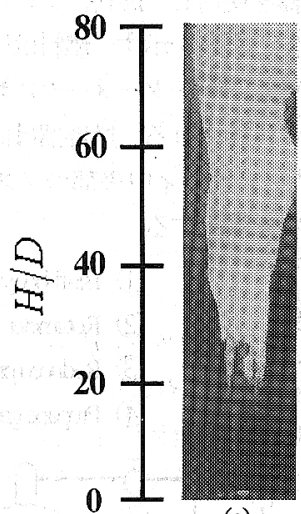

(a)

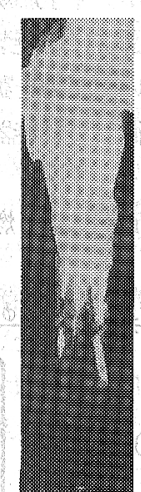

(b)

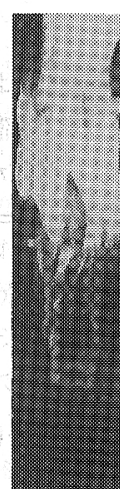

(c)

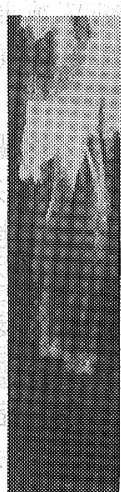

(d)

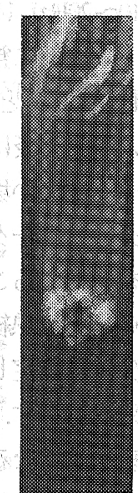

(e)

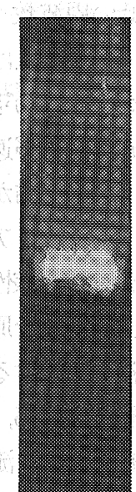

(f)

$\mathrm{U}_{\mathrm{j}}=14.1 \quad \mathrm{U}_{\mathrm{j}}=18.9 \quad \mathrm{U}_{\mathrm{j}}=23.6$

$\mathrm{U}_{\mathrm{j}}=30.7$

$\mathrm{U}_{\mathrm{j}}=40.1$

$\mathrm{U}_{\mathrm{j}}=47.2$

Fig.9 Instantaneous images of the natural lifted flame at increasing velocities, $U_{j}[\mathrm{~m} / \mathrm{s}]$ 
撮影した画像から HD を算出し，この值を火炎の状 態量として用いた.

図 12 に噴流の流速 $\mathrm{v}$ とアクチュエーターの入力周波 数 $\mathrm{f}$ 変化させた場合の火炎画像と 5 秒間の HD の変 化を示寸.ただし， 4 枚の画像は左から右に時間経過 しており $130 \mathrm{~s}$ 毎の火炎画像である. (ఏは初期状態 (H/D =20）の浮き上がり火炎であり，(b)〜(d)はアク チュエータ作動時の浮き上がり火炎である. また, (b)〜(d)のグラフ中の $\Delta \mathrm{S}$ は，初期状態に対する火炎基 部（部分予混合火炎）の面積変動を表すものであり， 以下の式で定義している.

$$
\Delta S=\frac{S-S_{H / D=20}}{S_{d}}
$$

ただし， $S$ は噴流を与えた時の火炎基部面積, $S_{H / D=20}$ は初期状態における火炎基部面積, $S_{d}$ は ノズルの出口面積である.

図 12 (b)と(c)は, 入力周波数が $10 \mathrm{~Hz}$ で流速が異な る場合である. 同一周波数のため流速による影響の みが表われている. いずれの場合も，噴流によって 火炎のリフト高さが大きく抑制されていることが分 かる. 特に $\mathrm{v} \geqq 2.0[\mathrm{~m} / \mathrm{s}]$ の場合（図 $12(\mathrm{c})$ ），噴流が 火炎に吹き付けられた瞬間（火炎画像の両端）にお いて H/D =0 付近にまで抑制されている.これは火 炎がノズル出口に完全再付着したことを意味し，火 炎の吹き飛びや逆火を誘発する危険性が高い，また， $\Delta S$ も最大となり，噴流により火炎全体の形状が乱 れてしまっている. 笠木らによると, 噴流の周波数 が低い場合，大きな速度変動が時空間的に安定な火 炎伝播を妨げると言われている ${ }^{2)}$. したがって, 低周波領域の噴流では, リフト変動が大きく火炎の 吹き飛びを誘発しやすいと考えられる.

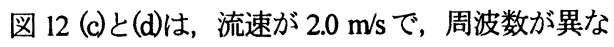
る場合である. $\mathrm{f}=10[\mathrm{~Hz}]$ の場合（図 $12(\mathrm{c})$ ) に比べ て, $\mathrm{f}=30[\mathrm{~Hz}]$ の場合（図 12 (d)) では, リフト高さ の抑制効果は小さいが， $\Delta S$ は最小であり火炎画像 を見ても形状の乱れはほとんどない，笠木らによる と, 噴流の周波数が高い場合, 燃料流速及び混合気 濃度の変動が低减されると言われている ${ }^{2)}$. した がって, 高周波領域の噴流では, 燃料流速と火炎伝 播速度が釣り合う位置が時空間的に安定に存在して 火炎が保持されると考えられる.

ここで, SSJA の周期的噴流が火炎のリフト高さ が低减するメカニズムについて考察する，噴流によ って火炎内側せん断層に乱れが誘起され ${ }^{2)}$ ，火炎
基部上流において周囲空気と燃料の混合が促進され る.これにより可然混合気を含む混合層が発達し， 火炎基部での部分予混合燃焼がノズル軸の中心付近 まで行われるため, 部分予混合火炎の基部位置 (リ フト高さ）が低減すると考えられる.

以上より SSJA の浮き上がり火炎に対する効果に ついて以下にまとめる.

（1）噴流の流速が速いほど，火炎のリフト高さの 抑制効果は大きい.

（2）噴流の周波数が低いほど，火炎のリフト高さ 抑制効果は大きいが，火炎形状を乱し，火炎 の吹き飛びを誘発する危険性がある.

（3）リフト高さの抑制効果は，噴流の流速よりも 周波数による影響が大きい.

以上から，浮き上がり火炎のリフト高さを安定し て抑制するには，噴流の流速と周波数の関係が重要 であることが分かる. そこで, SSJA の浮き上がり 火炎に対する有効範囲を明確にするために，図 13 のようなマップを作成した. 図は初期状態（H/D 20）の浮き上がり火炎に対するアクチュエータの 有効範囲であり, 横軸はアクチュエータへの入力電 圧, 縦軸は噴流の平均流速である. $\mathrm{H} / \mathrm{D}$ の範囲を 3 つの領域に分けて評価しており，H/D の值が小 さいほどリフト高さの抑制効果が顕著であることを 表している. 火炎の状態による最適なリフト高さが 分かっていれば, 図 13 のマップを用いてリフト高 さに応じた入力周波数と入力電圧を決定することが 可能である.

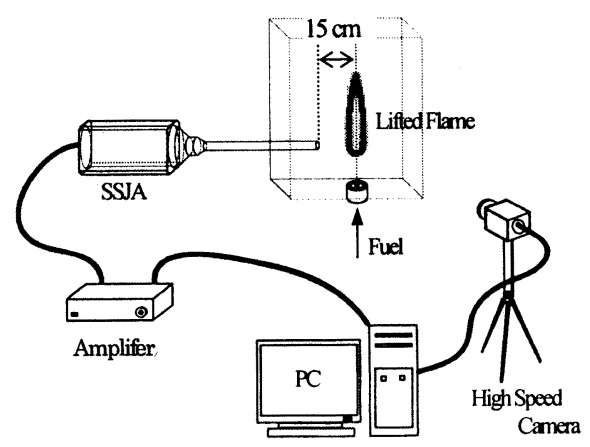

Fig.11 Schematic of the experimental setup 


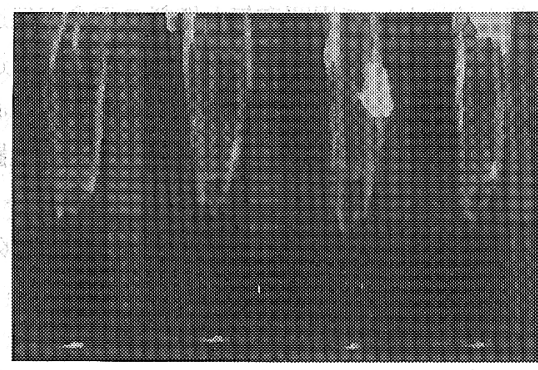

(a) The lifted flame without synthetic jet

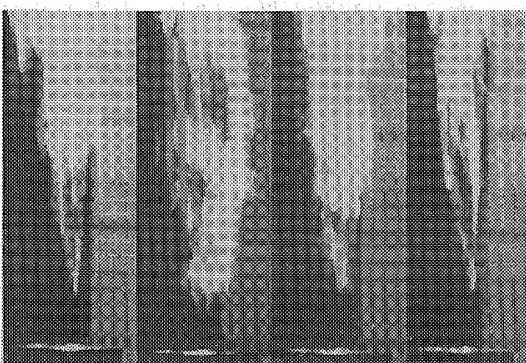

(b) $v=1.5 \mathrm{~m} / \mathrm{s}, \quad \mathrm{f}=10 \mathrm{~Hz}$

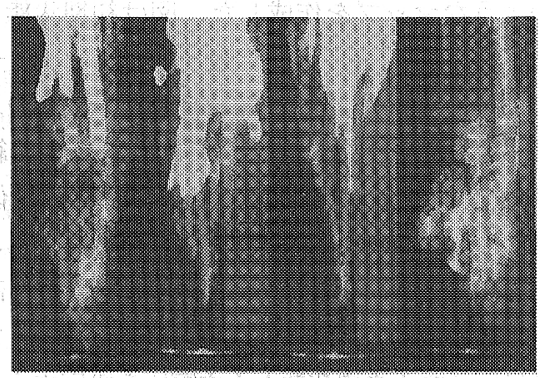

(c) $\mathrm{v}=2.0 \mathrm{~m} / \mathrm{s}, \mathrm{f}=10 \mathrm{~Hz}$

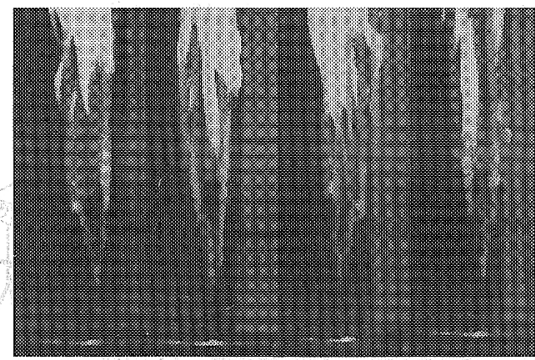

(d) $v=2.0 \mathrm{~m} / \mathrm{s}, \quad \mathrm{f}=30 \mathrm{~Hz}$
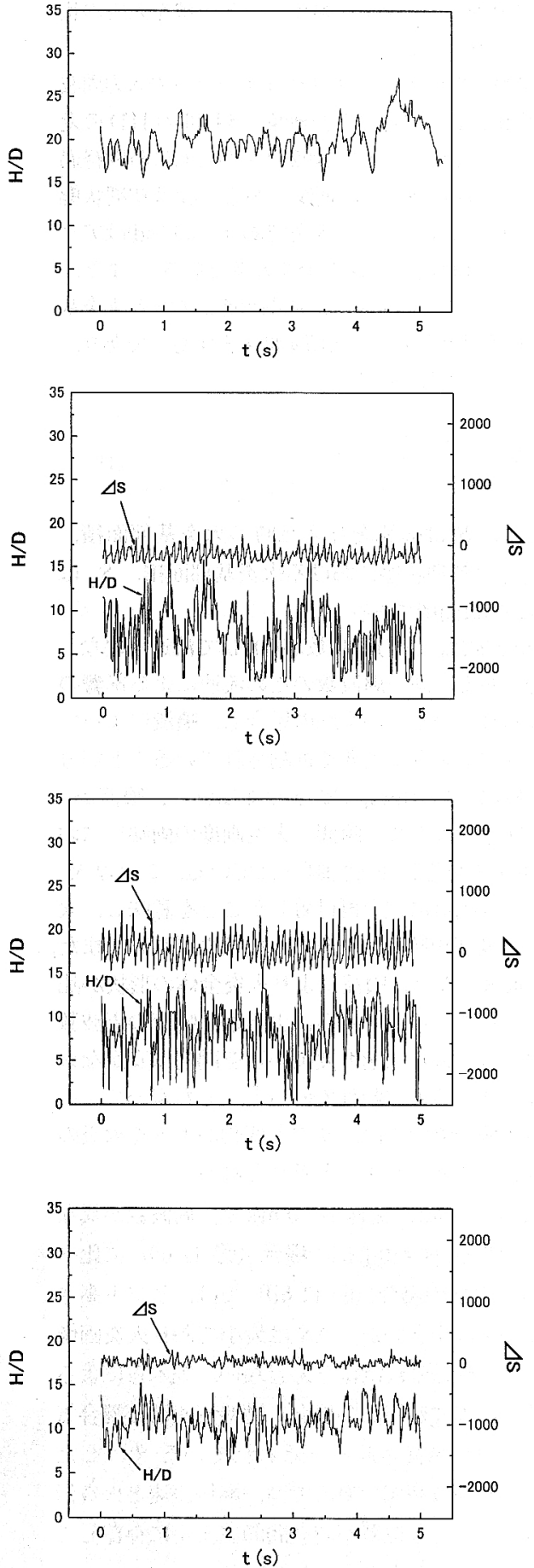

Fig.12 Instantaneous time-series images of the lifted flame per $1 / 30$ second $\left(\mathrm{U}_{\mathrm{j}}=25.9[\mathrm{~m} / \mathrm{s})\right.$ 


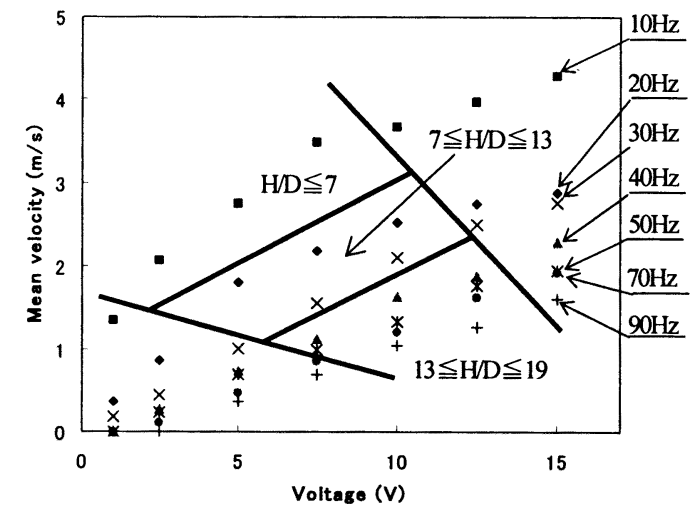

Fig.13 Effective map of SSJA

\section{5. 能動制御実験}

図 11 の実験装置を用いて火炎リフト高さの能動制 御実験を行った. 制御手法にカオス制御手法の一つで ある遅延フィードバック制御（DFC）を用いること で, システムの遅れ時間を考慮し，火炎のリフト高さ の変動の安定化を試みた.

5. 1 遅延フィードバック制御（DFC）ＤFCは， $\tau_{\mathrm{d}}$ 時刻過去の状態を目標值として, システムをリミ ットサイクルに収束させることを目的とする制御手法 である．遅れ時間を有するシステムにおいて発振を抑 制する効果が期待される. 目標軌道を蕨密に求める必 要がないため, OGY 制御と比較して簡便な手法であ るといえる ${ }^{6)}$. 目標周期 $\tau_{\mathrm{d}}$ やゲイン $K_{\mathrm{d}}$ の設定のよ っては発振が増幅されることもあり，理論的にパラメ 一タを決定することは難しい，ここでは，実験的にこ れらのパラメータを求めた. 図 14 に提案する制御シ ステムを示す.ここで, $x(t)$ は状態量， $u(t)$ は制御入 力, $r$ は目標值, $\tau_{\mathrm{d}}$ は目標周期である. 式(2)は DFC の制御則あり， $K_{\mathrm{n}}, K_{\mathrm{d}}$ はそれぞれ比例制御 と $\mathrm{DFC}$ の重みを表わす。 また, システムの 1 サ イクルの処理時間を $\tau_{\mathrm{s}}$ で定義した. 今回使用した計 算機では 1 サイクルの処理時間は約 $47[\mathrm{~ms}]$ であった. これに SSJA の動作時間を含め, $\tau_{\mathrm{s}}=0.1[\mathrm{~s}$ とした. 高 速度カメラによって火炎画像を取得した後, 計算機に おいてリフトの状態を推定する. 算出した HD の值 から式(2) と図 13 のマップに従ってアクチュエータ への入力を決定し, 火炎のリフト高さを目標とする状 態に制御寸る.

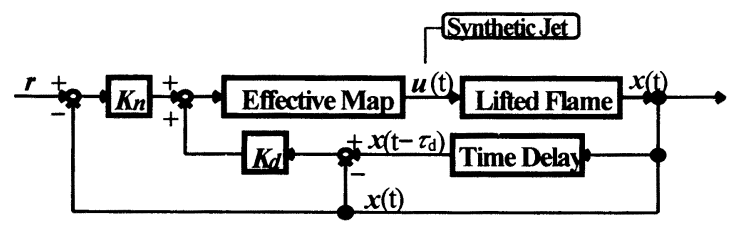

Fig.14 Active Feedback Control System

$$
\begin{aligned}
u(t)= & K_{n}\left(r-x\left(t-\tau_{s}\right)\right) \\
& -K_{d}\left(x\left(t-\tau_{s}-\tau_{d}\right)-x\left(t-\tau_{s}\right)\right)
\end{aligned}
$$

5. 2 実験条件及び実験方法 前章で述べたよ うに, SSJA のリフト抑制効果は噴流の流速が速く, 周波数が低いほど大きい，また，噴流の周波数がリフ 卜抑制に与える影響は流速よりも顕著であったが，低 い周波数は火炎形状を乱し吹き飛びを誘発する危険性 が高い，本実験では，火炎のリフト高さの抑制とリフ 卜高さの抑制とリフト変動の安定化を目的とするため, 比較的周波数が高く安定してリフトを抑制できる 45Hzを選択した.

実験は，浮き上がり火炎基部に対して噴流を噴出 し，火炎リフト高さを目標值まで抑制する，さらに DFC によってリフトの変動を安定に保つように制 御をかける. 前章と同様に燃料流速は $\mathrm{U}_{\mathrm{j}}=25.9[\mathrm{~m} / \mathrm{s}]$ とし, $\mathrm{H} / \mathrm{D}=20$ に固定した. 目標值 $r$ は $45 \mathrm{~Hz}$ のリ フト抑制範囲から $r=12$ とした. 比例制御ゲインは $K_{\mathrm{n}}=1.0$ とし, 目標周期 $\tau_{\mathrm{d}}$ やグイン $K_{\mathrm{d}}$ はパラメー タとして変化させた.

5. 3 実験結果及び考察 図 15, 図 16に実験結 果を示す. $100 \mathrm{~s}$ よりアクチュエータを作動させた. 両図共に $0 \sim 100 \mathrm{~s}$ までは制御を施していない状態で あり, 火炎の摇らぎのため $\mathrm{H} / \mathrm{D}$ が非定常に変動し ている. 図 15 はアクチュエータの入力周波数 $45 \mathrm{~Hz}$, 入力電圧 $8.4 \mathrm{~V}$ に固定して制御をかけない場合であ る.

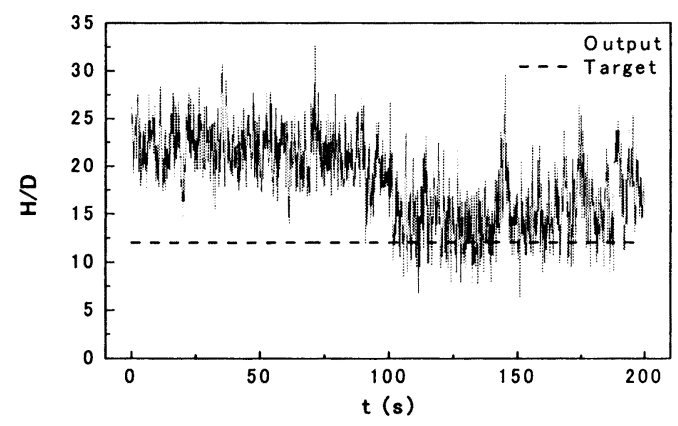

Fig. 15 Experimental results without active control 
図 16 は, アクチュエータの入力周波数は $45 \mathrm{~Hz} て ゙$ 固定し, 入力電圧に変化を加えて DFC を適用した 場合である. このとき $\tau_{\mathrm{d}}=1.0[\mathrm{~s}], K_{\mathrm{d}}=2.0$ に設定した.

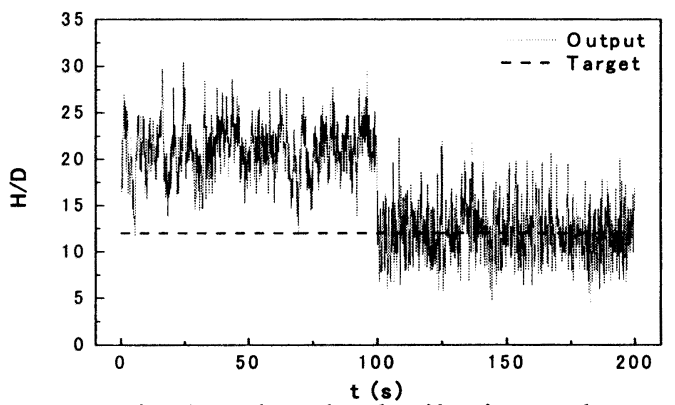

Fig. 16 Experimental results with active control

$$
\left(\tau_{\mathrm{d}}=1.0 \mathrm{~s}, K_{\mathrm{d}}=2.0\right)
$$

図 15 と図 16 を比較すると, 能動制御の有無に関 わらず 100 s以降の $\mathrm{H} / \mathrm{D}$ は目標值近くに抑制されて いることが分かる. しかし, 出力一定の場合（図 15）は，抑制後の H/D の変動が大きく $150 \mathrm{~s}$ 付近か ら不安定となっている.これに対して DFC を適用 した場合（図 16）では，H/D が目標值近くで安定 して抑制されていることが分かる.ここで，実験結 果を定量的に評価するために，以下の式で表される 評価関数 $\sigma$ を用いる.

$$
\sigma=\frac{\sigma_{1}+\sigma_{2}}{2}
$$

ただし， $\sigma_{\mathrm{r}}$ はリフト高さ $\mathrm{H} / \mathrm{D}$ の標準偏差, $\sigma_{2}$ は目標値との残差である. $\sigma$ の值が小さいほど, H/D が目標值近くに安定して抑制されていること を表している. 実験結果から計算した $\sigma$ の值を表 1 に示す．(a)〜(d)は, DFC 有りで $\tau_{\mathrm{d}}$ と $K_{\mathrm{d}}$ の值を変 化させた場合である.

Table.1 Estimation of stability for DFC

\begin{tabular}{|r|l|c|c|c|}
\hline \multicolumn{2}{|c|}{} & $\sigma_{1}$ & $\sigma_{2}$ & $\sigma$ \\
\hline \multicolumn{2}{|c|}{ Without DFC } & 3.59 & 4.87 & 4.23 \\
\hline \multirow{4}{*}{ With } & $\left(\right.$ a) $\tau_{d}=1.0 K_{d}=2.0$ & 2.87 & 2.93 & 2.90 \\
\cline { 2 - 5 } DFC & $\left(\right.$ b) $\tau_{d}=1.0 K_{d}=3.0$ & 3.34 & 3.36 & 3.35 \\
\cline { 2 - 6 } & $\left(\right.$ c) $\tau_{d}=2.0 K_{d}=2.0$ & 3.26 & 3.30 & 3.28 \\
\cline { 2 - 6 } & $\left(\right.$ d) $\tau_{d}=3.0 K_{d}=2.0$ & 4.41 & 4.83 & 4.62 \\
\hline
\end{tabular}

(a)，(b)は， $\tau_{\mathrm{d}}$ が同じで， $K_{\mathrm{d}}$ が異なる場合である. $\sigma_{1}, \sigma_{2}$ ともに $K_{\mathrm{d}}=2.0$ の方が小さい.

(a)，(c)，(d) は $K \mathrm{~d}$ が同じで, $\tau_{\mathrm{d}}$ が異なる場合であ る. $\tau_{\mathrm{d}}=1.0[\mathrm{~s}]$ と $\tau_{\mathrm{d}}=2.0[\mathrm{~s}]$ の場合に顕著な差は見られな
いが， $\tau_{\mathrm{d}}=3.0[\mathrm{~s}]$ の場合は $\sigma$ が最大となっており，DFC なしの場合よりも不安定な発振状態に陥っている.

以上から， $\tau_{d}=1.0[\mathrm{~s}], K K_{d}=2.0$ において, H/Dを目標 值近くに最も安定して制御することができた.

\section{6 結 言}

浮き上がり火炎安定化ためにスピーカー型シンセ ティックジェットアクチュエータ（SSJA）を提案 した. SSJA の構成には，その噴流特性から縮流部 と整流部をそれぞれ二つ備えた Type G を適用した. シンセティックジェットの流速と周波数を変化させ, 浮き上がり火炎のリフト 抑制に対する効果を調査 した. その結果, 噴流の流速が速く，周波数が低い ほどリフト抑制効果が大きいことが分かった。 また, 噴流の周波数がリフト抑制に与える影響は流速より も顕著であった．次に，噴流周波数を $45 \mathrm{~Hz}$ に固定 して遅延フィードバック制御（DFC）手法を用い た火炎リフト高さの能動制御実験を行った．その結 果 $\tau_{\mathrm{d}}=1.0[\mathrm{~s}], K_{\mathrm{d}}=2.0$ において，火炎を目標值近く に最も安定して制御することができた。

\section{文献}

1) 上島光浩・ほか 4 名 : 高温空気流中における浮 き上がり噴流火炎の予混合化燃焼と NOx 低减,

機論, 71-701，B(2005), pp.310-315

2）栗本直規，鈴木雄二，笠木伸英：マイクロアク チュエータ群による噴流拡散火炎の能動制御、 日本機械学会熱工学講演会講演論文集, pp.451452(2001)

3）栗本直規，鈴木雄二，笠木伸英 : 同軸噴流又夕 ン拡散火炎の浮き上がり構造の能動制御，第 41 回伝熱シンポジウム, pp.195-196(2003)

4) Y.C Chao,D.C Wu and C.H Tsai : Effects of Acoustic Excitation on the Combustion and Pollution Emission Characteristics of a Jet Flame, IJ.Trans. Phenomena, Vol.2 No.3(2000)

5) Daniel E. Paxson, Mark P. Wernet and Wentworth $T$. John : An Experimental Investigation of Unsteady Thrust Augmentation Using Speaker-Driven Jet, $42^{\text {nd }}$ AIAA Aerospace Sciences Meeting and Exhibit, pp.1-12(2004)

6) 潮俊光 : カオス制御，朝倉書店, pp33-36(1996) 